\title{
EPIDEMIOLGICAL STUDIES ON LEPROSY IN GIFU PREFECTURE
}

\author{
IV. SUMMARY \\ Hiroichi KITANO \\ (Tuberculosis Prevention Section, Department of Public Health, Ministry of Health)
}

Though the number of fresh cases of leprosy have decreased in recent years in Gifu prefecture, the total number of patients in the leprosarium and in private homes has increased by 21 in the past 20 years due to decrease in mortality. Including undetected cases, it is believed that there are 246 cases $(1.58$ per 10,000$)$ at the present time.

The number of non-hospitalized patients, being treated at home, have decreased by 113 in the past 20 years and there are only 24 known cases at present $(0.15$ per 10,000$)$. Of these, $46 \%$ are over 60 years of age and more than 11 years have elapsed since onset in $71 \%$. It will be a difficult problem however, to induce these patients to enter leprosaria and reduce the number of home patients.

The small number of home patients with the L-form, the marked shift to the right in the age distribution curve both in the total number and in the fresh cases, the high proportion of cases in which 11 years or more have elapsed since onset, the type ratio $(\mathrm{L} / \mathrm{M}+\mathrm{N})$ in fresh cases and the reduction in sex ratio all suggest that the epidemic of leprosy in Gifu prefecture is nearing the end of its course. Gifu has reached the average level of the whole country and can no longer be considered a leprosy prevalent prefecture. It must be noted however, that the incidence of leprosy in Koreans living in the prefecture is abnormally high.

It can be assumed that the number of undetected cases has decreased sharply due to the program of early examination and detection. It has been said that there are about 15,000 leprosy patients, including undetected cases, in Japan but it is believed that this number is too high and ca. 13,000 (1.46 per 10,000) is considered more closer to the actual number. 


\title{
岐阜県に於ける癩の疫学的考察
}

\author{
第 4 篇 総 括 \\ 北 野 博 一 \\ 元岐㚖得衛生部予防課, 現厚生省公篦衛生局結核予防課 \\ （1958年 6 月 4 日受稿）
}

\section{第 1 章 緒訔}

我が国の霜患者は逐年減少し，昭和30年末には療養所 入所中の患者 10,542 名, 未収容在宅患者 1,113 名, 計 11,655 名で，未発見の潜在患者を加えても約 15,000 名 と推定 ${ }^{1}$ さ秃ている。而して全国各都道府県衛生当局の 瀨予防に関する熱意は終戦後次第に高まり，潜在患者の 発見及び未収容在宅患者の入所锥奖等の努力が次第に効 果学げつつ女る現在, 向 $3,000 \sim 4,000$ 人の潜在患者 が存するか否がいて影念の存する所である。

余法昭和11 30年の 20 年間に於ける肢㚖罢の癩患者新 発生, 患者動態, 未収容在宅患者につき調査し, 既往の 潜在慧者 (未発見発病者) む把握し得たので, 岐皁県の

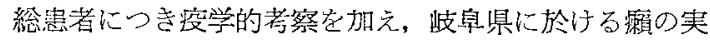

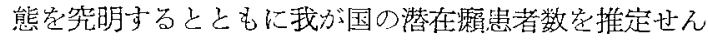
と試みた次第である。

\section{第2章 考按}

第 1 節 既往の資料による岐皋俱の嬾患者数 5 年目每に行われだ䅋患者の全国一䧻調查は主として

Table 1. 全国一窂調秀時の歧鼻県患者数

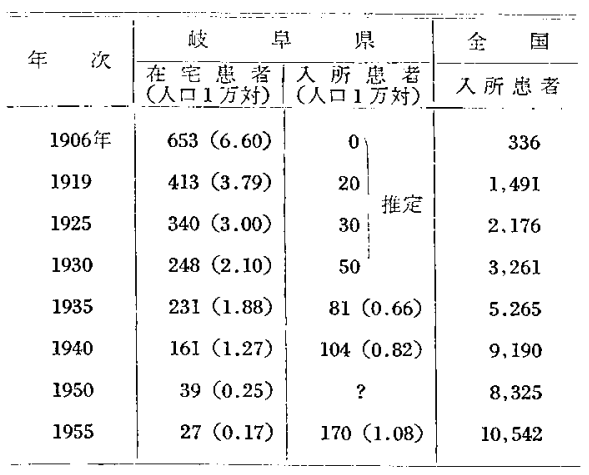

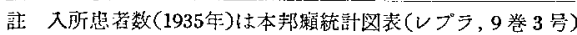

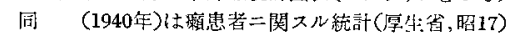
同（1955年）は日本のらい1955(藤烟協会)より
禾収容在宅虫者についてであつて, 療盖所入所患者は療 養所所在地の患者として計上された。また療盖所患者統 計は忠者の本籍地別又は入所前居住地別の虫者数のみ多 計上されて性別或は病型等につき出身地別の資料梳無 である。患者注その出身地安知られることを忌避して療 美所所在地化本籍を移寸者或注入所前居住地を偽る者む 相当数あることは想像に難くなく，正確を期し難い。し かしその概要后知ること法出来る。これらの资料による 岐㚖県の患者数注第 1 表の如くである。

明治 39 年には人口 1 万対 6.60 と高率江存在した在宅 患者は逐年著明に減少した。療着所入所患者数は昭和 10年，15年，30年の数字の夕判明していて他注不詳であ るが，全国の入所患者数より跂臭県出身患者老明治年代 は 0 名, 大正年代注 $20 \sim 30$ 名, 昭和 5 年活 50 名であつた と推定卞る。

この推定入所患者を加光ると第 1 図化示守如 $<$, 昭和 30 年までに総患者数は653名より198名（人口 1 万対 6.60 より1.25）に減少した。

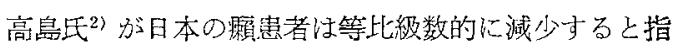
摘したのは古いことに属するが，翄皋県の患者数は昭和

Fig. 1. 忮皇県の灃患者減少状沇

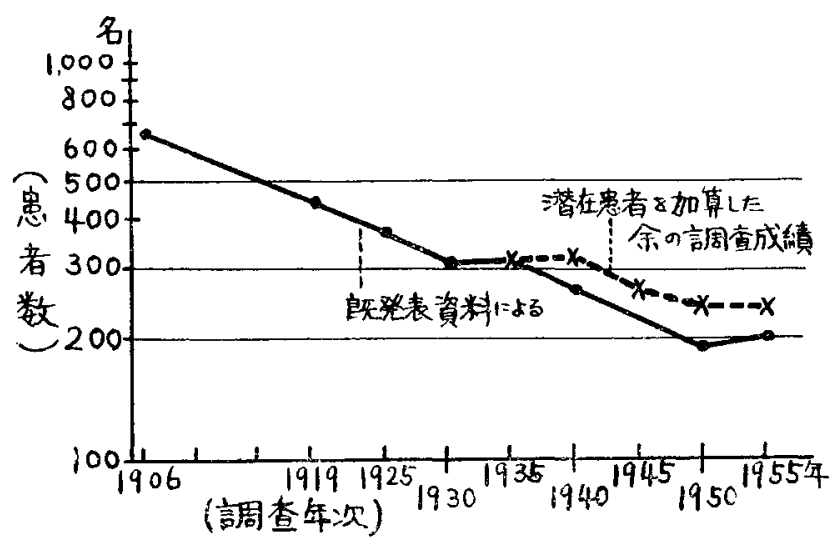


5 年まで等比級数的減少寺示した。その媵の減少状沇は 不規䐣である。

第 2 節 潜在患者学加算した調査成績及び日本の総患 者数

患者動態より5 年目每の在宅㶳者数及び入所患者数を 算出し，また新登見虫者の発病から発見までの期間を潜

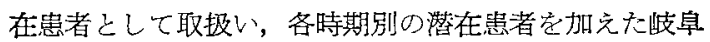
県の総忠者数柱第 2 表の如くである。

Table 2. 潜在患者紊加えた肢帛県患者数 （各年12月末日現在）

\begin{tabular}{|c|c|c|c|c|c|}
\hline 年次 & 在毛患者 (\%) & 入所患者 (\%) & 潜在患者 (\%) & 合部( & 舒 1 召 \\
\hline 1935年 & $137(44.5)$ & $72(23.4)$ & $99(32.1)$ & $308(100.0)$ & 2.51 \\
\hline 1940 & 125 (39.3) & $110(34.6)$ & $83(26.1)$ & $318(100.0)$ & 2.51 \\
\hline 1945 & $88(33.3)$ & $102(38.7)$ & $74(28.0)$ & $264(100.0)$ & 1.74 \\
\hline 1950 & $40(16.5)$ & $183(75.6)$ & $19(7.9)$ & $242(100.0)$ & 1.57 \\
\hline 1955 & $24(10.4)$ & $206(89.6)$ & $\mathbf{x}$ & $230 \div x$ & $1.45+\alpha$ \\
\hline
\end{tabular}

潜在患者は昭和10年99名, 15年83名, 20年74名の多数 定算するが，これ性前及び戦争中の検骖業務の不徹底 と患者の多発によること学示与。終戦後は検診計画も綿 密且積極的となり, 衛生思想の普及により自登的に讋察

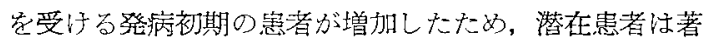
明に減少して昭和25年は僅かに19名となつた。

第 1 表及び第 2 表で昭和 10 年の在宅思者数に大差が見 られる。余の調査では後日非瀨と診定された者安除外し ているが，てれの攵では説明注不可能である。当時の一 斉調査は警察官によつてなされたもので容疑患者或は単

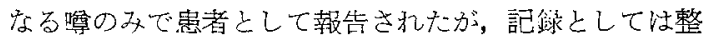
備されで恕者台帳に登载されないため後日医師による診 定が不可能のまま経過した者も相当数に達すると想像さ れる。し加し潜在患者数肎加えた余の成績は一齐調查結 果已近㑭主る。

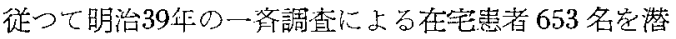
在患者学加觉た患者総数と考えることも不当ではない。

昭和30年療荃所入所患者数も第 1 表及び第 2 表で 36 名 の差を生じているが，逃走・転園等による再入所の際， 入所前居任地と出䙷地とが実際と相違したためと考え る。

潜在患者数汗単純に 1 年平均新発見亮者数と発病後発 見本での年数との相乗積で表わされるとすれ代第 3 表の 如き推定数となる。

発病後発見までの平均年数江発見時期別のものと発病 時期別のものとあるが, 後者による場合は昭和 $21 ２ 5$ 年
Table 3. 岐筫辱の潜在患者の推定数

\begin{tabular}{|c|c|c|c|c|c|c|c|c|}
\hline \multirow{3}{*}{ 年次 } & \multirow{3}{*}{ 人 口 } & \multirow{3}{*}{$\begin{array}{l}\text { 新费者 } \\
\text { 発芫率 } \\
\text { ( 人口 } \\
10 \text { 対) }\end{array}$} & \multirow{2}{*}{\multicolumn{2}{|c|}{$\begin{array}{l}\text { 発病後発兌委 } \\
\text { での平均数 }\end{array}$}} & \multicolumn{4}{|c|}{ 洁 在患 者 数 } \\
\hline & & & & & \multicolumn{3}{|c|}{ 㩰 定走 数 } & \multirow{2}{*}{ 実数 } \\
\hline & & & 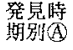 & $\begin{array}{l}\text { 発病時 } \\
\text { 期別 (B) }\end{array}$ & AKL & $(\mathrm{B})$ & 大よ\% & \\
\hline 1935年 & $1,225,799$ & 1.5 & 4.9 & 5.0 & 90 & & 92 & 99 \\
\hline 1940 & $1,265,024$ & 1.3 & 6.0 & 4.2 & 98 & & 69 & 83 \\
\hline 1945 & $1,518,649$ & 1.4 & 8.4 & 3.4 & 178 & & 72 & 74 \\
\hline 1950 & $1,544,538$ & 0.6 & 3.6 & 2.5 & 33 & 1 & 23 & 19 \\
\hline 1955 & $1,583,605$ & 0.5 & \multicolumn{2}{|c|}{2.0} & \multicolumn{3}{|c|}{15} & ? \\
\hline
\end{tabular}

の如く発病後10年以上の古い患者が $30 \%$ 以上を登見さ れる時期等の不合理安除去し得て誤差を少くすることが 出来方。

昭和31年以降の新虫者発見率が最近の全国の值 0.5 に 低下し，発病後平均 2.0 年で登見されると仮定寸狆ば， 昭和30年の推定潜在患者注15名となる。従つて患者総数 は 245 名となり，昭和 25 年と略々同数である。即台人廿 1 万対 1.55 で良来の日本の推定瀨患者数約 15,000 名の 人口 1 万対 1.68 より稍々低率である。

歧皇県に於ては最近霓患者の新発見が急减したにも拘 らず，潜在㭧者定加点た患者総数は第 1 図に示す如く徉 来の減少傾向が見られなくなつた。これは患者の生存年 数が延辰し，患者の死亡が急湤に減少したためである。

日本の潜在患者数劣肢帛県に準じて推定するに，将来 年間約 400 名（昭和30年は 412 名であつた）の新患者が

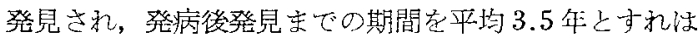
約 1,400名, 平均 2.5 年とす饵ば約 1,000 名となり, 昭 和30 年の月本の桷虫者総数は 13,055名〜12,655 名で約 13,000 名と推定し得る。従来の推定㭧者数より約 2,000 名少く, 人口 1 万刘 1.46 となる。

第 3 節 総虫者

昭和10年，15年，20年，25年，30年の各年末現在の潜

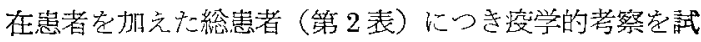
光。

(I) 年-命

総虫者の年令階級别分布状況は籍 4 表及び第 2 罒の如 くで，年令分布曲線の右矤が著明である。

新発見患者の発病年令曲線及び発見時年令曲線の右旋 が戦後著しいことは既に指摘した所であるが，総患者に ついても同様で青年層の患渚が次第に減少して，老年層 殊に70才以上の虫者の割合分溸增している。

外令分布劰線の右旋は全国的現象で全国患者に於てむ 第 5 表及び芴 2 図の如く顕著であるが，歧㚖県ではく39 $140<$ 及び $<19 / 60<$ がともに全国のそれよりも小とな 
Table 4. 伎帛県患者の年命階級別分盾

\begin{tabular}{|c|c|c|c|c|c|}
\hline 命階級 & 1935 年 $(96)$ & $19404(9)$ & 1945 年 $(\%)$ & 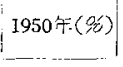 & 1955年(\%) \\
\hline $0 \sim 9 才$ & $7(2.3)$ & $0(-\cdots)$ & $2(0.8)$ & $1(0.4)$ & $2(0.9)$ \\
\hline $10 \sim 19$ & $42(13.6)$ & $42(13.2)$ & $29(11.0)$ & $16(6.6)$ & $9(3.9)$ \\
\hline $20 \sim 29$ & $77(25.0)$ & $70(22.0)$ & $69(26.1)$ & $54(22.3)$ & $40(17.4)$ \\
\hline $30 \sim 39$ & $73(23.7)$ & $80(25.2)$ & $59(22.3)$ & $60(24.8)$ & $57(24.8)$ \\
\hline $40 \sim 49$ & $44(14.3)$ & $52(16.4)$ & $59(22.3)$ & $57(23.6)$ & $49(21.3)$ \\
\hline $50 \sim 59$ & $33(10.7)$ & $36(11.3)$ & $17(6.5)$ & $23(9.5)$ & $43(18.7)$ \\
\hline $60 \sim 69$ & $27(8.8)$ & $29(9.1)$ & $18(6.8)$ & $18(7.4)$ & $16(6.9)$ \\
\hline $70 才 以 上$ & $4(1.3)$ & $9(2.8)$ & $11(4.2)$ & $13(5.4)$ & $14(6.1)$ \\
\hline 年命不詳 & $1(0.3)$ & $0(\rightarrow)$ & $0(-)$ & $0(-)$ & $0(-)$ \\
\hline s十 & $308(100.0)$ & $318(100.0)$ & $264(100.0)$ & $242(100$ & 230 \\
\hline 平枃年命 & 35.8 & 37.9 & 37.2 & 40.0 & 42.6 \\
\hline$\leqq 39 / 40 \leqq$ & 1.84 & 1.52 & 1.51 & 1.18 & 0.89 \\
\hline$\leqq 19 / 60 \leqq$ & 1.58 & 1.11 & 1.07 & 0.55 & 0.37 \\
\hline
\end{tabular}

Table 5．全国患者の年令階級別分布

\begin{tabular}{|c|c|c|}
\hline 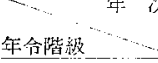 & 1935 年 & 1955年2) (96) \\
\hline $0 \sim 97$ & $51(0.3)$ & $53(0.5)$ \\
\hline $10 \sim 19$ & $1.082(7.1)$ & $487(4.1)$ \\
\hline $20 \sim 29$ & $3,521 \quad(23.2)$ & $2.102(17.9)$ \\
\hline $30 \sim 39$ & $3,797(25.0)$ & $3.139(26.7)$ \\
\hline $10 \sim 49$ & $2,969(19.6)$ & $2,729(23,2)$ \\
\hline $50 \sim 59$ & $2,070(13.6)$ & $1,805(15.3)$ \\
\hline 60 质以上 & $1,246(8.2)$ & $1,448(12.3)$ \\
\hline 年分不毇 & $2(0.0)$ & $2(0.0)$ \\
\hline 㐨 & $15,193(100.0)$ & $11.765(100.0)$ \\
\hline 平均年令 & 39.5 & 41.3 \\
\hline$\leq 39 / 40 \leqq$ & 1.25 & 0.96 \\
\hline$\leqq 19 / 60 \leqq$ & 0.67 & 0.37 \\
\hline
\end{tabular}

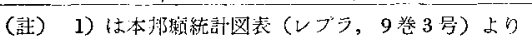

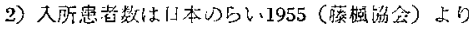

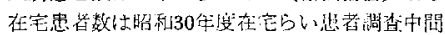
悻告(厚生省プりント)よりとつて果計したもの

り，一層右揟の傾向定示している。

(II) 発病後の経過年数

発病後の経過仺数は第 6 表及び第 3 図の如く, 経過年 数10年以内の患者は $58.8 \%$ (昭和18年)，51.2\%(15年)

$50.0 \%$ (20售)，45.5\% (25年)，33.5\%（30年）之順次 減少して古い患者が漸増している。即ち治瀨薬の効果或 は結核死亡の娍少等により瀨患者の生存年数が延長して いることと新登病者の減少の影響である。

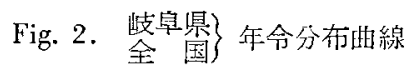

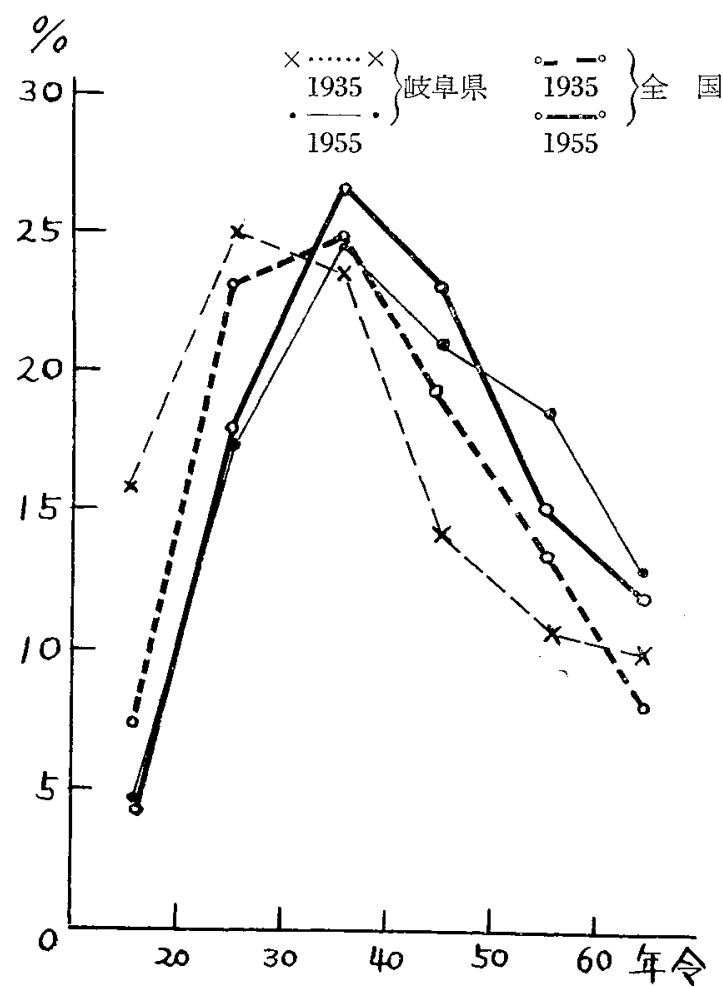

Fig. 3. 発病後経過年数の百分率の推移

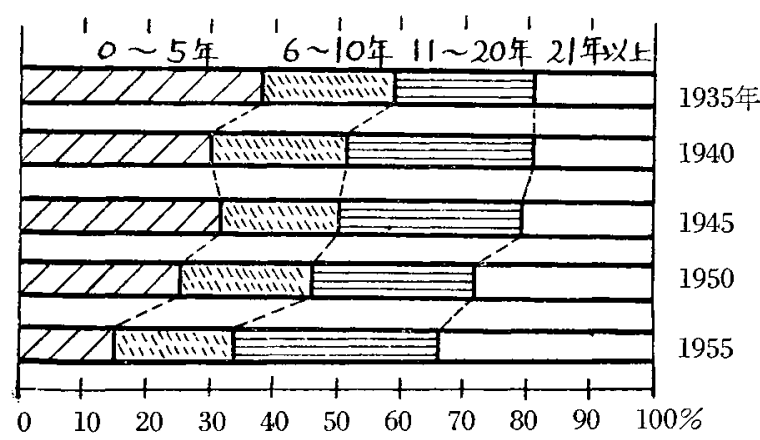

Table 6. 発病後の経過年数

\begin{tabular}{|c|c|c|c|c|c|}
\hline 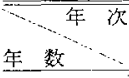 & 1935 年( $(9)$ & 1940 年( (\%) & 1945 年 (定) & 1950 年 $(\not 6)$ & 1955年(\%) \\
\hline $0 \sim 5$ 年 & $116(37.7)$ & $94(29.5)$ & $83(31.4)$ & $61(25.2)$ & $34(14.8)$ \\
\hline $6 \sim 10$ & $65(2.1 .1)$ & $69(21.7)$ & $49(18.6)$ & $49(20.3)$ & $43(18.7)$ \\
\hline $11 \sim 20$ & $69(22.4)$ & $95(29.9)$ & $77(29.2)$ & $63(26.0)$ & $74(32.2)$ \\
\hline 21 年以上 & $58(18.8)$ & $60(18.9)$ & $55(20.8)$ & $69(28.5)$ & $79(34.3)$ \\
\hline 計 & $308(100.0)$ & $318(100.0)$ & $264(10$ & $242(100.0)$ & 2300 \\
\hline
\end{tabular}


（III）病型及び性別

総患者の病型及び性別注第 7 表の如くである。

Table 7. 病型及び性別

\begin{tabular}{|c|c|c|c|c|c|c|}
\hline & & 1935年(\%) & I940年(\%) & 1945年 $(\%)$ & 1950 年 (\%) & 1955 年 (\%) \\
\hline & & ! & & & 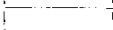 & \\
\hline & 計 & $\begin{array}{l}308(100.0) \\
?\end{array}$ & $318(100.0)$ & $264(100.0)$ & $242(100.0)$ & $230(100.0)$ \\
\hline 病 & $\mathbf{L}$ 型 & $161(52.3)$ & $177(5.7 .7)$ & & $143(59.1)$ & $142(61.7)$ \\
\hline & M 型 & $43(14.0)$ & $44(13,8)$ & $32(12,1)$ & $32(13.2)$ & $34(14.8)$ \\
\hline 型 & $\mathrm{N}$ 㤠 & $102(33.1)$ & $96(30.2)$ & $77(29.2)$ & $67(27.7)$ & $54(23.5)$ \\
\hline I & 病栕不言 & $2(0.6)$ & $1(0.3)$ & $1(0.4)$ & $0(-)$ & $0(-)$ \\
\hline 性 & & $217(70.5)$ & & $168(63.6)$ & $151(62.4)$ & $143(62.2)$ \\
\hline & 우 & $91(29.5)$ & $99(31.1)$ & $96(36.4)$ & $91(37.6)$ & $87(37.8)$ \\
\hline & 㪁㚖県 & 1.31 & 1.26 & 1.41 & 1.44 & 1,61 \\
\hline$/$ & 金在宅 & $?$ & 0.75 & $?$ & $?$ & 0.40 \\
\hline+ & 土! 大新 & 2.12 & 1.67 & 1.56 & $?$ & 1.70 \\
\hline & 《尌 & $?$ & 1.20 & $?$ & $?$ & 1.46 \\
\hline & 岐星显 & 2.39 & 2.21 & 1.75 & 1.67 & 1.64 \\
\hline \% & 全 在宅 & 2.39 & 2.31 & $?$ & $?$ & 2.40 \\
\hline & 大间 & 2.45 & 2.15 & 2.01 & 1.73 & 1.75 \\
\hline & ? 話 & 2.41 & 2.22 & $?$ & $?$ & 1.81 \\
\hline
\end{tabular}

年令については（一）の方向の浸染度前進現象即方癩 病勢の衰退が癹められるに反し，病型別では $\mathrm{L}$ 型の渐増 即当病型比の增加究示して一晃矛盾なるが如き結果であ る。こ礼はL型患者の死亡が減少し，二次的に生存患者 のL型の割合が増加しているためであつて，新発生患者 の病型はその発病時期別にも発兒時期別にも最近L型淢 少が著しく，なた在宅患者も著しく減少したので危除視 す当必要は必い。淀型比の增加は全国的現象である。

性別は常に男子が多いが，性比注次第に娍少し昭和30 华には1.64となつた。全国患者の性比む同様に減少して

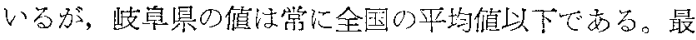
近死亡者の性比も減少しているのて，生存者の性比の減 少注として新発生患者の性比ぶー尿小であるここによ

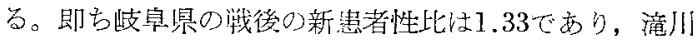
氏によ犼ば最近 3 ケ年間の全国新患者性比は 2.03 であ る。

\section{（IV）患者活身地}

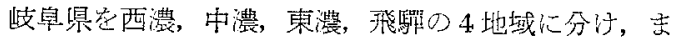
た他府県及び朝鮮出身者注患者数が少いので一括し，恚

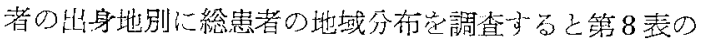
如くである。またこの地域別の病型化 $(\mathrm{L} / \mathrm{M}+\mathrm{N})$ 及

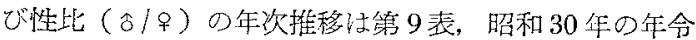

Table 8. 総患者の出身地別分有

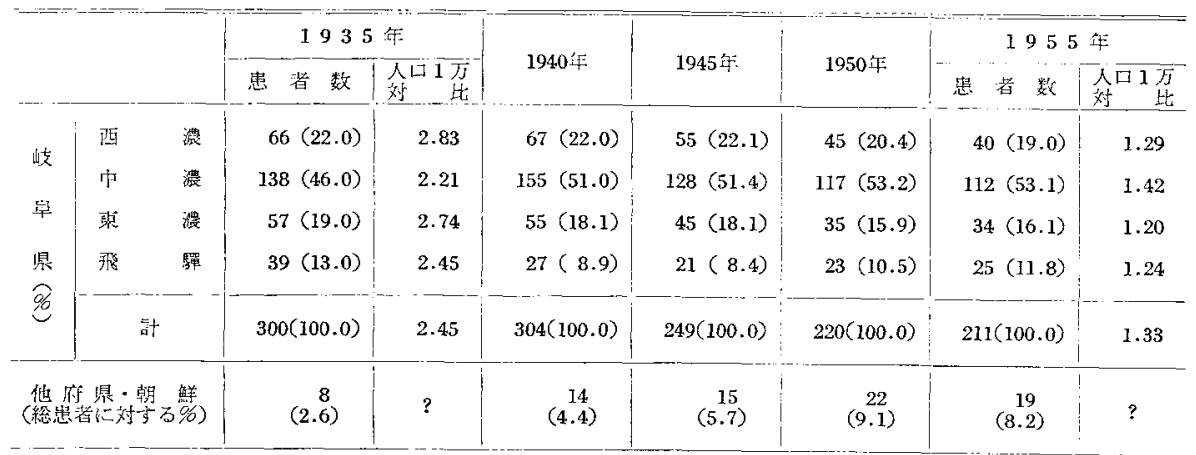

階級別分布㪀び平均年令は第10表の如くである。 これらの表について地域の特性を考察する。

1) 西濃: 総患者中に占める割合江戦後減少し始め, 人口 1 万対比は 20 年間に $1 / 2$ 以下となつた。現在病型比は 県下最低 (1.22) であり，性比も昭和 10 年は最高値 （3.40）であつたが急速に減少して平均值以下（1.50） に半減した。また平均年令㵊高である。これらの事军

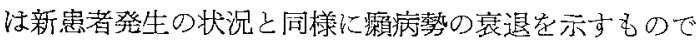
ある。

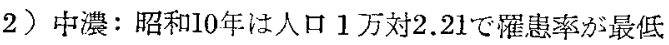

であつたが，次第に総患考中に占わる割合は増加し，現 在最高の䍜患率宗す。また病型比は次第に大きくな り，性比は常に平均值以上である。期ち瀨病勢は目内で 最も昰盛な㴍相学呈しているが，現在の年令分布で注60 于以上の老人が14.3\%に達する反面 20 才来满の若年者は $1.8 \%$ に過ぎず，近き将来急激に患者の減少を来たすも のと予想される。

3 ）東濃：人口 1 万対比が 20 年間に $1 / 2$ 以下となり，現 在帠下最低の罪患率である。しかし漸琙していた病型比 は最近平均以下ではあるが急増したこと，また平均年令 
Table 9. 地域別病型比及び性比の推移

\begin{tabular}{|c|c|c|c|c|c|c|}
\hline \multicolumn{2}{|c|}{ 地域 } & 1935年 & 1940年 & 1945年 & 1950年 & 1955年 \\
\hline \multirow{6}{*}{$\begin{array}{c}\mathrm{L} \\
\mathrm{M} \\
+ \\
\mathrm{N}\end{array}$} & 西 濃 & 1.32 & 1.28 & 1.57 & 1.37 & 1.22 \\
\hline & 中 湱 & 0.90 & 1.28 & 1.25 & 1.34 & 1.73 \\
\hline & 東 浀 & 1.38 & 1.20 & 1.14 & 0.94 & 1.43 \\
\hline & 我 驒 & 1.44 & 1.25 & 3.20 & 2.83 & 2.13 \\
\hline & $\left.\begin{array}{l}\text { 优付県 } \\
\text { 朝 鮮 }\end{array}\right\}$ & 0.60 & 1.33 & 2.00 & 2.67 & 1.71 \\
\hline & 平 均 & 1.11 & 1.26 & 1.41 & 1.44 & 1.61 \\
\hline \multirow{6}{*}{ ô } & 西 濃 & 3.40 & 1.91 & 1.61 & 1.65 & 1.50 \\
\hline & 中 濃 & 2.73 & 2.52 & 1.91 & 1.66 & 1.73 \\
\hline & 東 濃 & 1.71 & 1.89 & 1.50 & 1.50 & 1.43 \\
\hline & 飛 鲾 & 1.60 & 2.00 & 1.33 & 1.56 & 1.50 \\
\hline & $\left.\begin{array}{l}\text { 他付県 } \\
\text { 朝 鮮 }\end{array}\right\}$ & 1.67 & 2.50 & 2.75 & 2.14 & 2.17 \\
\hline & 平 均 & 2.39 & 2.21 & 1.75 & 1.67 & 1.64 \\
\hline
\end{tabular}

Table 10．1955年地域別年令分布

\begin{tabular}{|c|c|c|c|c|c|}
\hline 年令階級 & 西澄(名) & 中惯 $(\%)$ & 東漫 $(\%)$ & 形㬓( $(\%)$ & 化府県 $(\%)$ \\
\hline $\begin{aligned} 0 & \sim 9 才 \\
10 & \sim 19\end{aligned}$ & ${ }_{3}^{1}(10.0)$ & ${ }_{1}^{1}(1.8)$ & ${ }_{2}^{0}(5.9)$ & ${ }_{1}^{0}(4.0)$ & ${ }_{2}^{0}(10.5)$ \\
\hline $\begin{array}{l}20 \sim 29 \\
30 \sim 39\end{array}$ & ${ }_{10}^{3}$ & ${ }_{29}^{21}(44.6)$ & $\begin{array}{c}6 \\
10\end{array}$ & ${ }_{3}^{7}(40.0)$ & ${ }_{5}^{3}(42.1)$ \\
\hline $\begin{array}{l}40 \sim 49 \\
50 \sim 59\end{array}$ & ${ }_{10}^{8}(45.0)$ & $\mid \begin{array}{l}25 \\
19\end{array}(39.3)$ & $\begin{array}{l}9 \\
5\end{array}(41.2)$ & ${ }_{3}^{5}(32.0)$ & ${ }_{6}^{2}(42.1)$ \\
\hline $\begin{array}{l}60 \sim 69 \\
70 \text { 才以上 }\end{array}$ & ${ }_{3}^{2}(12.5)$ & $8(14.3)^{\prime}$ & $1(5.9)$ & ${ }_{1}^{5}(24.0)$ & ${ }_{1}^{0}(5.3)$ \\
\hline 計 & $40(100.0)$ & $112(100.0)$ & $34(100.0)$ & $25(100.0)$ & $19(100.0)$ \\
\hline 平均年命 & 43.5 & 43.3 & 39.7 & 43.4 & 40.8 \\
\hline$\leqq 39 / 40 \leqq$ & 0.74 & 0.87 & 1.13 & 0.79 & 1.11 \\
\hline$\leqq 19 / 60 \leqq$ & 0.80 & 0.13 & 1.00 & 0.17 & 2.00 \\
\hline
\end{tabular}

は最も若く 40 子前後比は県下最大となつたこと等は病萓 の再燃戞疑わし放。新患者発生の状況とともにこの地 域に対寸る今後の監視が蚛化されね仗ならな。

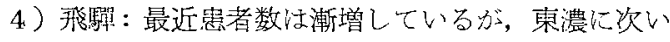
で低い霍患率で西る。病型比は颀下最大でめるが，これ は 1 世带 6 名（L型 6 名, M型 1 名）の瀨家族の発見の ためである。現在患者の年令分布では60才以上の老人が 24\%にも達し，他の地区に悓られない現象である。家 族感染の特殊事例はめつたが新患者の発生からも，総患 者の内容加ら，この地区は病勢の衰遈期に入つている と考える。

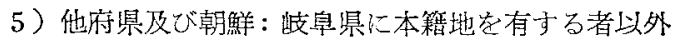

の割合は次第に増加した。殊にそれ䋛媵の朝鮮人患者 の発見のためで，男子沛女子に比して著しく多く，年令

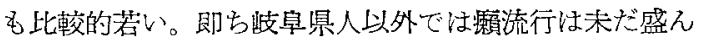
である。

第4節 末取容在宅患者について

明治39年 653 名を算した未収容在宅患者は順調に減少 して昭和 30 年末には24名となつたここの減少を明治39年 を100とする指数で示し．全国，隣県の需知県及び岐㚖 県安比較すると夫々 $4.8,7.1,3.7$ となり，臤阜県の減 少度汇要知県の約 2 倍である。ほた在宅患者の人口 1 万 対比注昭和 30 年末現在, 全匤は0.13, 愛知県は 0.18 , 岐 皋県は0.15である。

在宅患者 24 名の年令分布, 病型, 性別, 出身地, 登病 後経過年数怔第11表，第12表の如くである。

Table 11. 在宅患者の病型別・性別年令分布 (1955年)

\begin{tabular}{|c|c|c|c|c|c|c|c|c|c|}
\hline & L & 型 & M & 型 & $\mathrm{N}$ & 型 & \multicolumn{2}{|c|}{ 合 } & 計 \\
\hline & $\hat{\circ}$ & 우 & $\hat{o}$ & of & $\hat{\delta}$ & 우 & $\widehat{\partial}$ & 우 & 訫 \\
\hline 0〜29才 & 0 & 0 & 0 & 0 & 0 & 0 & 0 & 0 & 0 \\
\hline 30 39 & 0 & 1 & 0 & 1 & 0 & 0 & 0 & 2 & 2 \\
\hline $40 \sim 49$ & 0 & 0 & 1 & 1 & 1 & I & 2 & 2 & 4 \\
\hline $50 \sim 59$ & 3 & 1 & 1 & 1 & 1 & 0 & 5 & 2 & 7 \\
\hline 60才以上 & 2 & 0 & 1 & 2 & 3 & 3 & 6 & 5 & 11 \\
\hline \multirow{2}{*}{ 計 } & 5 & 2 & 3 & 5 & 5 & 4 & \multirow{2}{*}{13} & \multirow{2}{*}{ 1I } & \multirow{2}{*}{24} \\
\hline & \multicolumn{2}{|c|}{7} & \multicolumn{2}{|c|}{8} & \multicolumn{2}{|c|}{9} & & & \\
\hline 平均年令 & \multicolumn{2}{|c|}{54.4} & \multicolumn{2}{|c|}{55.6} & \multicolumn{2}{|c|}{63.6} & 59.0 & 57.4 & 58.3 \\
\hline$\leqq 39 / 40 \leqq$ & \multicolumn{2}{|c|}{0.17} & \multicolumn{2}{|c|}{0.14} & \multicolumn{2}{|c|}{0} & 0 & 0.22 & 0.09 \\
\hline
\end{tabular}

Table 12. 在宅患者の出身地別経過年数 - 病型 - 性別

\begin{tabular}{|c|c|c|c|c|c|c|c|c|c|}
\hline 出 & 身 & 地 & 別 & 西㗛 & 中浱 & 棵賑 & 哥楼 & 他府県 & $(\%)$ \\
\hline \multirow{4}{*}{ 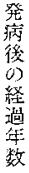 } & \multicolumn{3}{|c|}{$0 \sim 5$ 年 } & 3 & 1 & 0 & 0 & 0 & 4. (16.7) \\
\hline & & \multicolumn{2}{|c|}{$6 \sim 10$} & 1 & 2 & 0 & 0 & 0 & $3(12.5)$ \\
\hline & & \multicolumn{2}{|c|}{$11 \sim 20$} & 1 & 1 & 2 & 2 & 1 & $7(29.2)$ \\
\hline & & \multicolumn{2}{|c|}{ 21年以上 } & 2 & 3 & 4 & 0 & 1 & $10(41.6)$ \\
\hline \multirow[t]{2}{*}{ 俩 } & & L & & 0 & 3 & 1 & 2 & 1 & $7(29.2)$ \\
\hline & & M & & 6 & 1 & 1 & 0 & 0 & $8(33.3)$ \\
\hline 型 & & $\mathrm{N}$ & 型 & $\mathbf{I}$ & 3 & 4 & 0 & 1 & $9(37.5)$ \\
\hline 性 & & \multicolumn{2}{|c|}{$\hat{s}$} & 3 & 5 & 2 & 2 & 1 & $13(54.2)$ \\
\hline 別 & & \multicolumn{2}{|c|}{ 우 } & 4 & 2 & 4 & 0 & 1 & $11(45.8)$ \\
\hline \multicolumn{4}{|c|}{ मीt } & 7 & 7 & 5 & 2 & 2 & $24(100.0)$ \\
\hline
\end{tabular}

平均年今は 58.3 才で 30 才未蔽の患者は 1 名もなく60才 
以上の老人が男子 $46 \%$ ，女子 $45 \%$ に達している。严 病後の経過年数も11年以上の古い患者が71\%を占め終戦 後の発病者汪少い。日本の在栄患者の現状3（60才以上 26\%）に比し老人患者方゙多く且古い患者が大部分である ことは療荃所への収容に際し大きな障害となり、これら の患者の死亡定待つ以外に在宅患者数の急激な减少は哇 まれない状洗となつた。

平均年命は $\mathrm{L}$ 型 $<\mathrm{M}$ 型く $\mathrm{N}$ 型となり, 性比性 $\mathrm{M}$ 型 $<\mathrm{N}$ 型く $\mathrm{L}$ 型の順である。全体の性比は1.18で最近の全国在 宅患者 ${ }^{31}$ ○2.40, 大阪府 ${ }^{41}$ の2.76, 要知県5) $02.780^{1 / 2}$ 以下である。こ机は发孚県の総患者の性比がー一般に小で あることのみに起区するのではなく，男子患者の療養所 への理解が高かつたた的と考光る。病型比 $(\mathrm{L} / \mathrm{M}+\mathrm{N})$ は0.41で全国在宅患者の0.40と差がな, 大服府の0.30 より大きい。

出身地別には西濃及じ東濃が人日に比して患者は多い

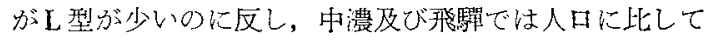
患者は少いが型が多く质険である。

\section{第 3 章 総括}

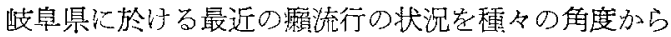
疫学的に考察し，次の如き結果を得た。

1）昭和11 30年の20年間の新発生患者注 335 名（人 口10万対 1 ケ年平均発生率 1.2) であるが，その開未曾 有の第 2 次世界大戦が众在するにも拘らず，戦争の影響 により特に発病者が增加したとは認好らない。しかし 戦争中及び終戦直後の湿乱期には検診業務は不十分とな り，患者発見率は低下したが，秩序の回復とともに発見 率は戦後最大となつた。最近は登病者も次第に減少し て，発見率注戦前の約 $40 \%$ 程度（人口10万対 0.6 ) 飞減 少したが，最近の日本の顁発見率 (0.5) 上り僅かに高 W。

患者死亡数沙 20 年間に 253 名で，ての中自殺が 9 名 (3.8\%) に羍し，一般日本人の自殺件数に比し稍々高 率である。死亡は最近激減して戦争中の約 $1 / 4 に$ 過ぎず, 死亡率は思者 100 に対し 2.39 となつた。

新患者の登生注調に減少したにも拘らず死亡の減少 が台一層顕著であつたため，昭和 5 年までは岐㚖県に於 ても等比級数的に総虫者の琙少定みたが，最近の20年間 では21名の堌加学招来し, 昭和30年末現在の総患者数は 230名となつた。而して潜在虫者数安加光た総患者数は 昭和15年以降む減少していたが，最近注減少也ず現在 245名子推定され，人口 1 万対1.580虫者岩接し，余の

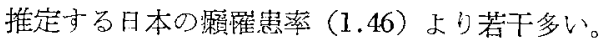

2）20年間に療養所へ収容した患者恃延 360 名で，退 所延83名, 療養所内死亡143名に及び, 現在入所中の患 者浪 206 名である。新発見患者の療養所入入所し治療の 経験学持つた者は78\%に達した。忠者の発兒より入兹ま

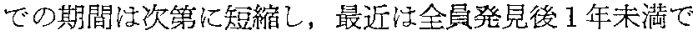
入所している。

収容に努力したため未収容在宅忠者は20年間に113名 減少して昭和 30 年末現在 24 名となつた。この琙少速度は 全国平均より稍々大で，明治時代瀨濃厚県であつた岐皋 県悓在の在宅患者数人口 1 万対 0.15 となり，日本の平 均（0.13）に近付いた。しかしながら60才以上の老人患 者が多く，再三の入所誘奖に心じなかつた発病後11年以 上の古い患者が71\%に達すること収容の大きな障害で ある。その病型比が0.41でし型の少いことは不幸中の幸 と言うべきである。

3）新患者の発病より発見までの期間は最近非常に短 䋹し, 発病後 2 年以内の思渚が過半を占わるに至り, 古 い患者の発見は著しく減少した。従つて潜在忠者の数も 僅少となつた。新患者の発病年令分布曲線及び発見時年 令分布曲線は已もに戦後右旋し，(一) の方向の浸染度 前進現象茥呈寸る。殊に最近は老人の発病が多く，発病

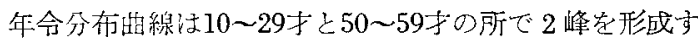
る。総虫者についても闰様に在故が認められ，全国患者 よりも右旋が一層顕著である。た登病後の経過年数別 に総害者を及る10年以内の者の率独次第に減少し，現 在は11年以上経た古い魯者が $2 / 3$ に達している。これは新 患者の発生減少，死亡の減少，生存年数の延等に上 名。

全死亡者の平均死亡年令は45.2才である沛，20年間に 11.7 年の上杽空来たし，最近は男子 52.1 才，女子 58.3 才 となったしかし台，一般日本人に比して約10年生存年 数は短縮している。平均死亡年令の上显は発病年令の上 昇（戦前平均26.5才 $\rightarrow$ 最近の平均 38.3 子）にもよるが， 発病より死亡までの罹病年数が次第に延長（戦前平均 16.7年 $\rightarrow$ 最近の平均21.4年）していることにも由来主 ba

病型比は新患者の発病時期別にみると次镜に減少し， 特に最近 5 ケ年間は $\mathrm{M}$ 型の登病が増加して 0.85 となつ た。また死亡者の病型も最近し型の減少が影著で，総患 者の病型比僅からつではあるが增大している。

性比は新患者全体で女子 100 K対し男子 165 と衣り， 彷来の諸家の報告に比して男子ダ少いが，最近益々ての 男女間の差が少くなりつつある。従つて総患者の性比も 次第に淢少して昭和30年は女子 100 に対し男子164 とな 
つた。在宅患者の性比は現在女子 100 に対乙男子 118 と 極度に小さく，全国及び他府県の1/2以下である。

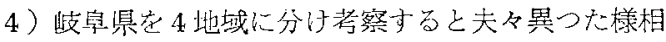
总呈する。

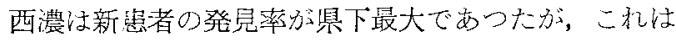

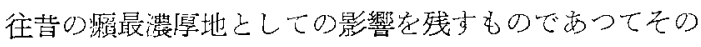
内容注行末期の状態で多。また総忠者数の人口 1 万

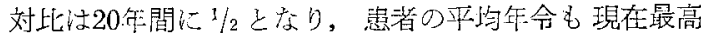
となり，病型比及び继比が小さく，在宅患者にL型がＩ 名も存在しないこと等活病繁衰退の結果である。

中濃法新舁者について妇総患者についても病等衰退の 徵は認奶られず, 現在総患者の人口 1 万対比は1.42で県

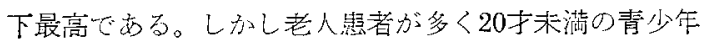
患者の少いことは近き将来の減少が予想されるが, 在宅 患者にL型の多いことは新患者発生の感染源となること が危惧される。

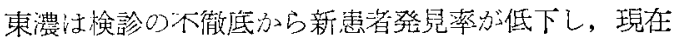

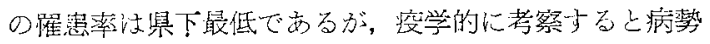
再然の徽が認的方机，今媵監視が必要であ。

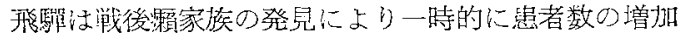
哭来たしたが，全般的には病势集退期に入つて居り，破 に現在は60才以上の老人患者が $24 \%$ 多きに達している ことは玧らしい。

5）新発兒患者の約 $10 \%$ は伎㚖辱に本籍地安有しない 外来者である。朝鮮人の発病率は人口10万対 $13.0 \sim 8.7$ 之見做さ和，目本人の10秥以上になり，疫学的心猖けつ

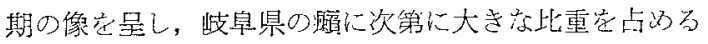
ようになつた。

\section{第 4 章 結 論}

昭和1〕〜30年の20年間に岐㚖県に於て発兒した瀨新㸃
者及び療荃所八の收容, 或は死亡等, 㿎患者の動態統計 について種々疫学的考察を試みるともに，岐鼻県に於 ける檞患者の総数及び在宅虫者数の変動について調查し た結果，次の如き結論を得た。

I ）歧㚖県に於ける澒の流行は疫学的に終末に近付き つつあつて, 往营の瀨澧厚県の地位を脱却し全国の平均 線に到達した。

2）最近瀨浔者死亡率の改善は顕著で，新䖵者の発生 淮減少したにも拘らず，総患者数は隇少するに至らず， 現状維持の状態汇今娞も暫時続くと考党る。

3）术収容在宅㭧者虫古い老人患者が多く，収容促進 注困難であり，早急交隇少は望以ない。

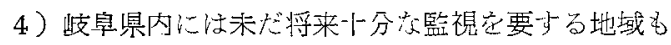
あり，また朝鮮人の発病率注異労に高摔であるので，患 者の早期発兒については今得も留意しなけ秃な゙なな w。

5）虫者の早期発鼠・早期涭唁が行われるようになつ たため潜在急者は韭常に減少した。证つて日本の触害者 総数江約 13,000 名（人口1万対1.46）と推定与る。

稿を終る心臨み，北海道大学安倍教授の微指尊亡御 校閲を感謝するとしもに，終始熱心に御略力いただい

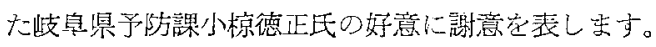

\section{参考 文 献}

1) 藤瓭閌会：口本のらいについて (1955)

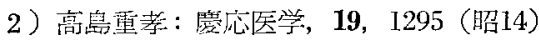

3 ）滰川勝人:レプラ，26,349(昭32)

4）志水靖博他：レプラ，23，159（昭29）

5 ）祖父江昭仁：レプラ，26，349（昭32） 